
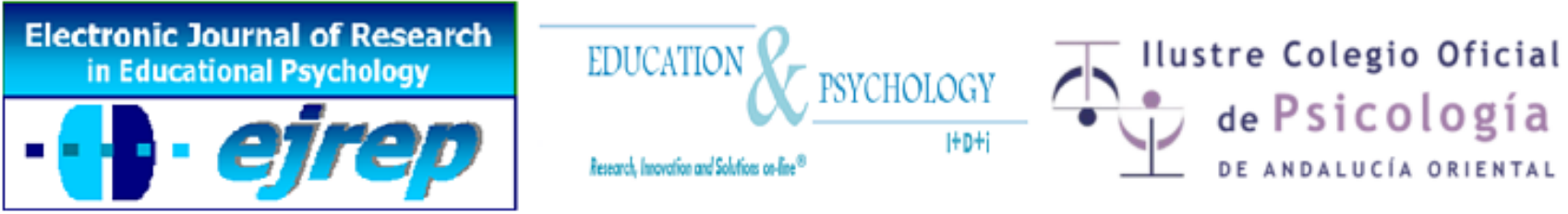

\title{
Game-like Tablet Assessment of Approaches to Learning: Assessing Mastery Motivation and Executive Functions
}

\section{Krisztián Józsa, ${ }^{1}$ Karen Caplovitz Barrett, ${ }^{2}$ \& George A. Morgan ${ }^{3}$}

\author{
${ }^{1}$ Institute of Education, University of Szeged, Szeged, Hungary \\ ${ }^{2}$ Human Development and Family Studies, Colorado State University, \\ Fort Collins, CO, USA \\ ${ }^{3}$ School of Education, Colorado State University, Fort Collins, CO, USA
}

\section{Hungary, USA}

Correspondence: Krisztián Józsa, Institute of Education, University of Szeged, 30-34 Petofi street, Szeged 6722, Hungary. Email: jozsa@edpsy.u-szeged.hu

(C) University of Almería and Ilustre Colegio Oficial de la Psicología de Andalucía Oriental (Spain) 


\begin{abstract}
Introduction. School readiness predicts both school and life success, so measuring it effectively is extremely important. Current school readiness tests focus on pre-academic skills; however, mastery motivation (MM: persistent, focus on trying to do a task) and executive functions (EF: planful self-control) are also crucial.
\end{abstract}

Method. The purpose of the paper is to give an overview of a new, computer-based assessment of $\mathrm{MM}$ and $\mathrm{EF}$.

Results. We have developed a game-like, computer-based assessment for 3 to 8 year-old children, of MM, EF, and recognition of numbers and letters. The new measures are appropriate for both Hungarian and American cultures. They were engaging for children of this age, and preliminary evidence suggests that they are reliable and valid.

Conclusion. The new tasks can be part of assessments of school readiness, and would be useful for school practice as well as researchers. The tasks ascertain the extent to which observed deficits in pre-academic domains are due to MM or EF difficulties. The results will contribute to the development of individualized intervention.

Keywords: mastery motivation, executive functions, school readiness, computer-based tasks 


\section{Resumen}

Introducción. La preparación para la escuela predice el éxito tanto en la escuela como en la vida, por lo que medirlo de manera efectiva es extremadamente importante. Las pruebas de preparación escolar actuales se enfocan en las habilidades preacadémicas. Sin embargo, la motivación de dominio (MM: persistente, concentrarse en intentar hacer una tarea) y las funciones ejecutivas (EF: autocontrol planificado) también son cruciales.

Método. El objetivo de este informe es ofrecer una visión general de una nueva evaluación basada en computadora de MM y EF.

Resultados. Hemos desarrollado una evaluación basada en computadora, similar a un juego para niños de 3 a 8 años, de MM, EF y reconocimiento de números y letras. Las nuevas medidas son apropiadas para las culturas húngara y estadounidense. Estaban comprometidos con niños de esta edad, y la evidencia preliminar sugiere que son confiables y válidos.

Conclusión. Las nuevas tareas pueden ser parte de las evaluaciones de la preparación para la escuela, y serían útiles tanto para la práctica escolar como para los investigadores. Las tareas determinan hasta qué punto los déficits observados en los dominios preacadémicos se deben a dificultades de MM o EF. Los resultados contribuirán al desarrollo de la intervención individualizada.

Palabras clave: motivación de maestría, funciones ejecutivas, preparación para la escuela, tareas basadas en computadora 


\section{Introduction}

In this paper, we describe a new tablet app aimed at addressing a crucial need in early education - for a reliable and valid, child-friendly, individualized school-readiness assessment that is efficient and easy for educators in authentic educational settings to administer and interpret. There is an abundance of research highlighting the critical importance of school readiness (e.g., Guernsey, Bornfreund, McCann, \& Williams, 2014) and of early childhood education as a means of improving school readiness, particularly for children from low SES backgrounds (e.g., Akers et al., 2015; Rathbun \& Zhang, 2016). Csapó, Molnár and Nagy (2014) have developed computerized school readiness tests for pre-academic skills, based on evidence that these skills are good predictors of success in 1st and 2nd grades. However, an essential school readiness domain that is rarely adequately assessed currently is Approaches to Learning (ATL).

ATL is an over-arching term for interrelated attributes that help children learn, such as enthusiasm, focus, persistence, flexibility, and mastery/competence motivation (e.g., Hyson, 2008; McDermott, Rikoon, Waterman, \& Fantuzzo, 2012). The National Education Goals Panel called ATL "perhaps the most important dimension of school readiness" (Kagan, Moore, \& Bredekamp, 1995), and "From Neurons to Neighborhoods" specifically highlighted mastery motivation as a key domain (Shonkoff \& Phillips, 2000). Yet, even though ATL is a key domain in 48 of 50 U. S. States' Early Learning Guidelines, it usually is assessed only by teacher report in current school readiness assessments. Our new app is unique in assessing two key aspects of ATL, namely mastery motivation (MM) and executive functions (EF), directly from children through a set of fun, game-like tasks. This enables us to distinguish related domains of ATL, making appropriate, individualized intervention possible. It also briefly screens for two areas of academic readiness (letter and number recognition).

It is clear that MM and EF are important for school success (e.g., Berhenke, Miller, Brown, Seifer, \& Dickstein, 2011; Józsa \& Barrett, 2016). In fact, there is evidence that MM and EF are even better predictors of later school performance than IQ (Diamond, 2016; Józsa \& Molnár, 2013). Despite their importance, there are no standardized behavioral tests of the mastery motivation of children during this critical transition from pre-school to elementary school, and 
few computer- or tablet-based assessments of either MM or EF. Before providing more information about the app and how it measures crucial but neglected aspects of school readiness, it is important to define $\mathrm{MM}$ and $\mathrm{EF}$.

\section{Mastery Motivation}

We define MM as a multifaceted psychological force that stimulates individuals to attempt to master a skill or task that is at least somewhat challenging (Barrett \& Morgan, 1995). "Multifaceted" refers to the fact that mastery motivation occurs in and may differ across various contexts and domains (e.g., cognitive, social: Barrett \& Morgan, 1995; Józsa, 2014b; Józsa \& Molnár, 2013; Wang \& Barrett, 2013). In addition, multifaceted refers to the idea that mastery motivation includes both expressive/affective aspects and instrumental aspects (Barrett \& Morgan, 1995; Wang \& Barrett, 2013). Affective aspects include positive emotions while mastering challenging tasks, as well as negative emotions at less successful and/or anticipated unsuccessful mastery. Instrumental aspects include goal-directed persistence and inclination to control and/or have impact on the environment. Thus, focused persistence and enthusiasm during challenging tasks are central, definitional measures of both MM and ATL. Moreover, measured MM shares important characteristics with another ATL, EF.

\section{Executive Functions}

EF is another broad term subsuming children's abilities to control their goal-directed attention, thoughts, and behavior. EF includes the ability to purposefully inhibit a well-learned or highly motivated but counter-productive response (inhibitory control), ability to hold thoughts in mind while solving problems (working memory), and ability to adjust strategies to changing contextual demands (cognitive flexibility). Executive functions provide an important foundation for learning in education settings (Zelazo, Blair, \& Willoughby, 2016). EF are required for the highlevel regulation and control of action, thought, and emotions, and seem to be based in the prefrontal cortex (Diamond, 2013; Müller \& Kerns, 2015; Zelazo \& Müller, 2010). Many researchers agree that the three core EF components are essential for both behavioral and physical health as well as success in school and in life (Blair \& Raver, 2015; Diamond, 2013; McClelland et al., 2007; Zelazo et al., 2016). They seem important, in particular, for successful transition to kindergarten, the focus of school readiness assessments (Blair \& Razza, 2007). Unfortunately, the role 
of motivation in EF has been neglected by most research (Peterson \& Welsh, 2014). Zelazo and Müller (2002) proposed that EF varies according to the motivational significance of a situation, classifying situations as emotionally charged ("hot" EF) or not ("cool” EF); however, more research is needed on the relation between motivation, and this distinction. Moreover, existing measures of EF do not take into account the role of MM, in particular, in EF performance.

\section{Differences between $M M \& E F$}

Both MM and EF are key, malleable ATLs manifested in goal-directed behavior despite challenge; yet, they also are different in important ways. MM involves children's attitudes/approach toward challenge, learning, and performance; and feelings of autonomy, desire/enthusiasm for mastery, and low/moderate negative emotion during mastery attempts (e.g., Barrett \& Morgan, 1995; Ratelle, Guay, Larose, \& Senécal, 2004). In contrast, EF seems to be more of a skill than an attitude, with rapid normative growth during early childhood. There is evidence that early interventions can increase MM (e.g., Hashmi, Seok, \& Halik, 2017; Vansteenkiste, Simons, Lens, Sheldon, \& Deci, 2004). Moreover, there also is evidence that EF can be improved through interventions (e.g., Bryck \& Fisher, 2012; Diamond \& Lee, 2011; Greenberg \& Harris, 2012). However, the types of contextual interventions that affect attitude and beliefs central to MM are quite different from those that enhance skills central to EF. Interventions to enhance MM typically involve affective- and autonomy-supportive teaching and fostering of emphasis on the learning process rather than performance (e.g., Sakiz, 2017; Schiefele \& Schaffner, 2015). In contrast, EF interventions typically involve practicing inhibitory control, cognitive switching, and working memory skills (e.g., Bierman \& Torres, 2016). Moreover, there is evidence that ATLs such as motivation and enthusiasm can mediate the role of preschool EFs in later reading skills and socioemotional competence (Sasser, Bierman, \& Heinrichs, 2015). It is therefore crucial to distinguish these two ATLs and measure both MM and EF.

Children's persistence, enthusiasm for learning and EF skills during challenging tasks are critical for school success, given that challenge is essential to academic progress (e.g., Berhenke, et al., 2011; Józsa \& Barrett, submitted; McDermott et al., 2011; McWayne, Cheung, Wright, \& Hahs-Vaughn, 2012; Willoughby et al., 2012). A recent longitudinal study found that the types of ATL that are measured by our app (attentional control, persistence, cognitive flexibility) predict- 
ed both academic and social competence in primarily low income, minority American children at age 9 (Martin, Razza, \& Brooks-Gunn, 2015). Some studies indicate that mastery motivation may be a better predictor of cognitive development than intelligence, playing a crucial role in school achievement (Józsa, 2007; Józsa \& Barrett, submitted; Józsa \& Molnár, 2013; Yarrow, Klein, Lomanaco, \& Morgan, 1975). MM and EF are the primary focus of the assessment we have developed.

We have developed an internet-based tablet assessment for 3 to 8 year-old children (see also Barrett, Józsa, \& Morgan, 2017; Józsa, Barrett, Józsa, Kis, \& Morgan, 2017; Józsa, Barrett, $\&$ Morgan, 2016), and we are in the process of evaluating an android version. Characteristics assessed include (a) mastery motivation (i.e., persistence in searching for letters and numbers in an increasingly challenging array); (b) executive functions (working memory, measured by ability to remember locations of pictures; inhibitory control and mental set shifting, measured by increasingly challenging card sorting tasks), and (c) recognition of numbers and letters. The assessment has two versions, one in English and one in Hungarian, and preliminary pilot data have been collected in Hungary and the U.S. using it. We have succeeded in creating tasks that are engaging for children of this age and preliminary data indicate that they are reliable and appropriately related to other measures (Józsa et al., 2017). The assessment does not require children to read, but the computer narrator, Little Bear, speaks in either English or Hungarian based the examiner's selection. The tasks were developed to be appropriate for both Hungarian and American cultures, and involve pictures of everyday objects and school-related symbols, including letters, numbers, animals, vehicles (boats, cars, and airplanes) and fruit. Children of both countries were readily able to do the easy level of all of the tasks.

Our tablet-based child-friendly tasks will be an important complement to existing school readiness tests, such as DIFER, the widely used Hungarian assessment. DIFER (A diagnostic system of assessment and criterion-referenced development) is a standardized Hungarian school readiness test battery (Nagy, Józsa, Vidákovich, \& Fazekasné, 2004a). It includes diagnostic assessment of the developmental level of seven pre-academic skills, each of which can be seen as a critical academic precondition to elementary school learning. DIFER provides information on what a child needs to know in each of these skill domains, helping teachers intervene to teach 
students appropriately (Nagy, Józsa, Vidákovich, \& Fazekasné, 2004b). The DIFER skills assessment is appropriate for determining pre-academic school readiness and also for predicting academic success at the beginning of schooling (Józsa, 2014b, 2016). However, DIFER does not include motivational or executive function variables, so it does not ascertain the extent to which observed deficits in the pre-academic domains are due to motivational or self-control (EF) difficulties. This has important implications for intervention to promote school success. If the underlying cause of the child's delayed pre-academic skills is low motivation and/or inability to maintain attention and inhibit impulsive responses, it is likely that including intervention to promote $\mathrm{MM}$ and/or EF would be more effective in promoting school success than tutoring on the preacademic skills alone.

\section{Our Previous Research}

Morgan and Barrett have been studying MM for more than 30 years (e.g., Morgan, Harmon, \& Maslin-Cole, 1990, Barrett and Morgan, 1995). Józsa began studying mastery motivation in 1998, and published his PhD thesis in this field (Józsa, 2003). As a result of Józsa's Dimensions of Mastery Questionnaire (DMQ) studies, more than 20,000 ratings of MM are available in Hungarian. Józsa pointed out that MM is strongly related to skill development in pre-school and early school years (Józsa, 2001, 2007). Mastery motivation also was found to predict school achievement more accurately than IQ (Józsa \& Molnár, 2013). With American and Chinese colleagues, Józsa investigated age changes in MM during the school years, using cross-sectional (Józsa, 2014a; Józsa, Wang, Barrett, \& Morgan, 2014), and longitudinal data-collection (Józsa \& Barrett, submitted; Józsa \& Morgan, 2014). Barrett, Morgan, and Józsa have also collaborated on a recent handbook on self-regulatory processes in development, including EF (Wang \& Barrett, 2013; Józsa \& Molnár, 2013; Morgan, Wang, Liao, \& Xu, 2013).

The development of our current game-like computer tasks is based on strong international cooperation between Józsa in Hungary and American colleagues Morgan, Barrett, and, more recently, Stevenson and Lewis. We are especially interested in how focused, planful, and persistent children are at mastering challenging tasks. Thus, we recently have developed the computer based assessment of mastery motivation and executive functions described in this article. We are using an individualized approach first developed by Morgan, Busch-Rossnagel, Maslin-Cole, \& 
Harmon (1992). These individualized moderately difficult tasks facilitate the separation of abilities from motivation, and this work has led to an increasied understanding of executive finctions and mastery motivation in children developing typically and also atypically (Berhenke, et al., 2011; Busch-Rossnagel and Morgan, 2013; Cuskelly, Gilmore, \& Carroll, 2013; Hauser-Cram Warfield, Shonkoff, \& Krauss, 2001; Wang, Morgan, Hwang, \& Liao, 2013; Wang, Morgan, Liao, Chen, Hwang, \& Lu, 2016).

\section{Research Goal}

The goal of this paper is to provide information about the tasks used in our new, tablet assessment of MM and EF. We provide examples of the screenshots included in the assessment, as well as the instructions that the computer narrator, Little Bear, gives children to guide them through the tasks. We also include tables showing a complete summary of the levels of each task, including the levels for which screen shots are not included.

\section{Overview of the New Computer-Based Tasks}

Seven computer-tablet, game-like tasks comprise this school readiness assessment. Number Recognition and Letter Recognition tasks serve as brief assessments of pre-academic abilities. Not only do these tasks provide some information on pre-academic skills; they may also help us distinguish the child's pre-academic knowledge from their motivation and executive functions.

Three additional tasks, Letter Search and Number Search, are primarily used to measure two important aspects of the child's Mastery Motivation: persistence and pleasure while trying to solve a challenging problem. These tasks vary in difficulty, and children are given tasks that are easy, moderate, and hard for most children their age. These tasks are used to assess the child's persistent focus on the task while they try to find all matches. By considering both persistence on these search tasks and children's competence on the EF tasks, we can assess the relative role of these two measures of approaches to learning in school readiness and success.

Two additional tasks are designed to assess aspects of Executive Functions. The Picture Memory task assesses working memory, children's ability to hold information in mind and to op- 
erate on it to solve a problem. The Size-Shape-Color Game (which is based on the Dimensional Change Card Sort task; Zelazo, 2006), requires two other EFs: self-regulated inhibition and mental set shifting. Self-regulated inhibition enables children to inhibit attention to irrelevant information and to prevent themselves from exhibiting undesired but dominant responses. It therefore helps children regulate impulses so a goal can be achieved. Mental set shifting allows the child to follow changing or conflicting rules during problem solving. Like the Dimensional Change Card Sort (DCCS) task, the Size-Shape-Color Game requires the child to not only remember (or figure out) the sorting rules but to respond to multiple rule changes on multiple sorting dimensions, and to inhibit responses consistent with previous rules. Our version has been modified to increase difficulty level at the higher levels, so that difficulty will not be defined by reaction time, as it is on some other versions of the DCCS.

Each of the tasks ranges in difficulty from easy for 3-year-olds to difficult for 8-year-olds. We break the administration of the seven tasks into two sessions, which may be held on the same day (separated by other activities) or on two different days. Each session lasts approximately 1520 minutes. One session includes the pre-academic tasks, which are counter-balanced in presentation order, and also the mastery motivation tasks, which are also counterbalanced with each other. The other session includes the two EF tasks (again counterbalanced).

This paper provides selected examples of the 103 screenshots and accompanying instructions that the computer narrator, Little Bear, gives children, which will help the reader understand the tasks from children's perspective. The paper also includes tables showing the levels of each task, including the levels for which screen shots are not included here. A summary of the seven tasks and appropriate time needed for each is presented in Table 1.

The session begins when the test administrator (who does not need to have had formal training in assessment) introduces him/herself to the children and explains that they are going to play some games on a computer tablet. The test administrator fills in the login screen with the experimenter's user identification number and password. 
Table 1.

Overview of the Seven Tasks

\begin{tabular}{lll}
\hline $\begin{array}{l}\text { Sequence } \\
\text { number }\end{array}$ & Task & Duration \\
\hline First Session: & Pre-Academic Skills and Mastery Motivation \\
1 or 2 & Number recognition & up to $1 \frac{1 / 2}{2}$ minutes \\
2 or 1 & Alphabet recognition & up to $1 \frac{1}{2}$ minutes \\
3 or 4 & Number search & up to about 8 minutes \\
4 or 3 & Letter search part 1 & $2-8$ minutes depending on the child's \\
& & age \\
5 & Letter search part 2 & $2-6$ minutes depending on the child's \\
Second Session: & Executive Functions Tasks & age \\
6 or 7 & Picture memory & \\
7 or 6 & Dimensional change card sort & up to about 8 minutes \\
\hline
\end{tabular}

\section{Session One of the Tasks}

The test administrator uses the login screen to enter the child's name (optional), ID number, and birth year and month (used to calculate age in months). Note, what the computer says is in quotations (if short) or indented (if longer) and italicized.

Figure 1 appears, and touching the bear starts the narration. Little Bear moves its mouth as a pre-recorded voice says, "Hello! My name is Little Bear. I am going to play with you today."

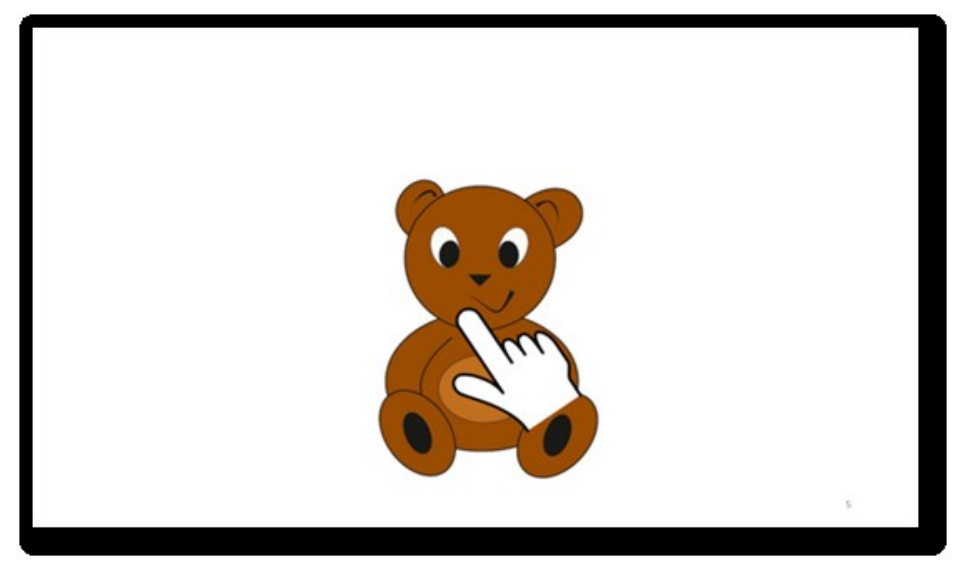

Figure 1. Touching Little Bear starts the narration. 


\section{Pre-Academic Abilities}

Training: Before each task there are training slides to help the child understand the type of task and provide help if the child does not initially know what to do; the ones for pre-academic skills are pictures of five animals (fish, bird, bunny, cat, and mouse).

Task 1 or 2. Number Recognition (tasks 1 and 2 are counterbalanced). The task is to visually identify numbers the child hears. After training, "Little Bear" says:

Now we will play a number game. First, I will say a number. Then, you will touch that number on the screen. For example, if I say '2', you will find and touch '2' on the screen. Only touch one number. When you touch it, a new screen will appear and I will tell you a new number.

Little Bear then says a number and the child needs to select and touch the correct numeral in an array of numbers. After the child touches a number (whether it is correct or incorrect), the array disappears, that trial ends, and a new array appears. The numbers get progressively more difficult with each trial. Our pilot testing suggests that 15 trials or fewer and a maximum of 90 seconds is sufficient to obtain a good measure of 3-8 year-old children's level of number recognition. When the child misses two Number Recognition trials in a row, the task ends and the computer goes to the next task. Table 2 shows the 15 levels of the Number Recognition task.

Table 2.

Difficulty Levels of the Number Recognition Task

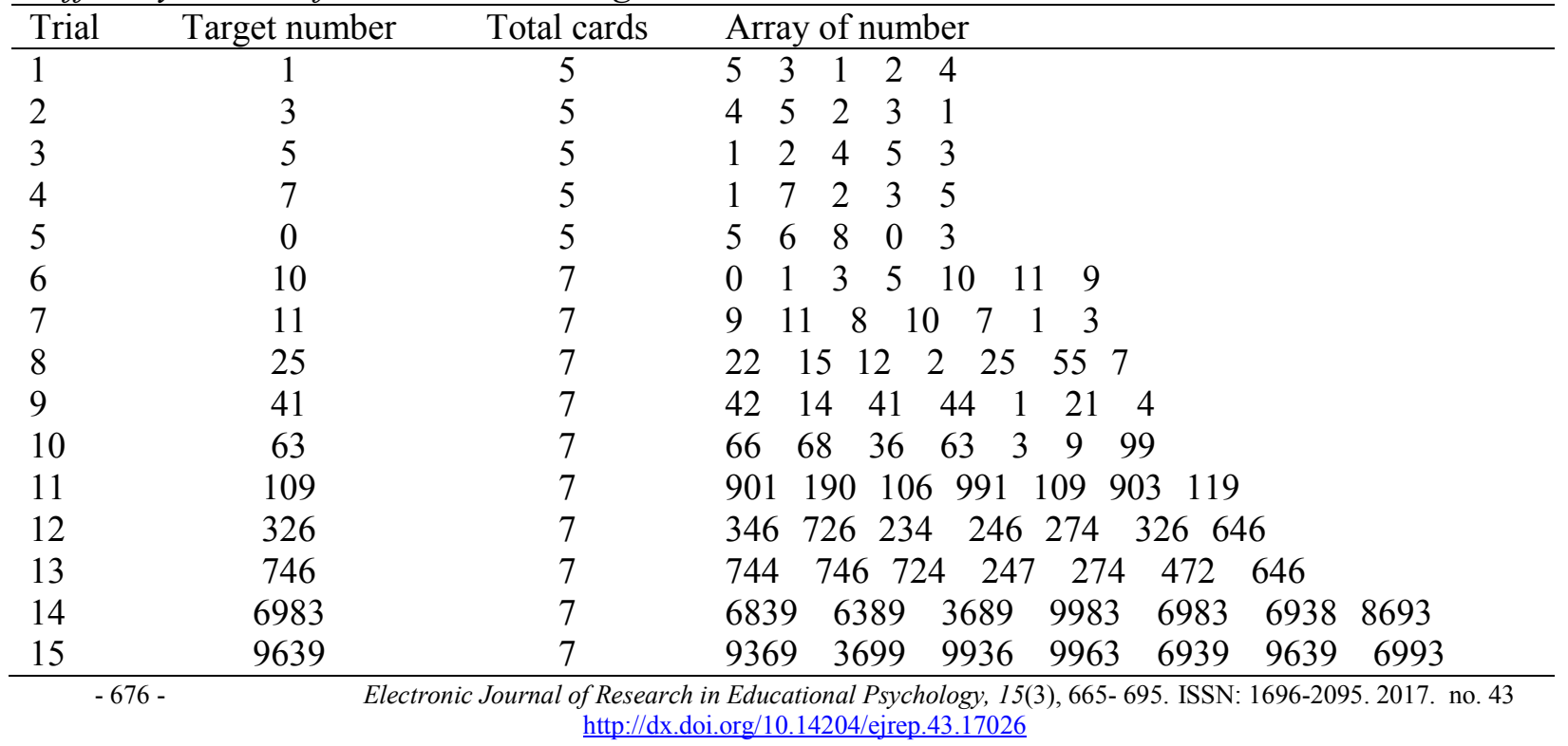


Task 2 or 1. Letter Recognition. The task is to visually identify letters that the child hears. Before Trial 1, "Little Bear" says:

Now we are going to play a game with letters. For this game, I will tell you the name of a letter. On the screen, touch the letter that you hear. For example, if I say 'A', find and touch 'A'. Only touch one letter. When you touch it, a new screen will appear and I will tell you a new letter to find.

Little Bear then says a letter and the child finds and touches it in an array of letters. As with number recognition, after the child touches one letter in an array (correct or not), all of the letters disappear, and "Little Bear" says a new letter. Again, tasks get progressively more difficult as trials progress. Pilot work again indicates that 15 trials, lasting 90 seconds, provide a good measure of the child's knowledge of letters. Table 3 presents the levels. The task ends when the child misses two consecutive letters.

\section{Table 3.}

Difficulty Levels of the Letter Recognition Task

\begin{tabular}{|c|c|c|c|}
\hline Trial & Target letter & Total cards & Array of letters \\
\hline 1 & $\mathrm{~A}$ & 5 & $\begin{array}{lllll}\mathrm{B} & \mathrm{C} & \mathrm{A} & \mathrm{D} & \mathrm{E}\end{array}$ \\
\hline 2 & B & 5 & $\begin{array}{lllll}D & B & A & C\end{array}$ \\
\hline 3 & $\mathrm{C}$ & 5 & $\begin{array}{lllll}A & E & B & C & D\end{array}$ \\
\hline 4 & Z & 5 & $\begin{array}{lllll}H & \mathrm{~S} & \mathrm{~T} & \mathrm{~B} & \mathrm{Z}\end{array}$ \\
\hline 5 & $\mathrm{~S}$ & 5 & $\begin{array}{lllll}\mathrm{Z} & \mathrm{S} & \mathrm{B} & \mathrm{A} & \mathrm{R}\end{array}$ \\
\hline 6 & G & 5 & $\begin{array}{lllll}Q & C & B & A & G\end{array}$ \\
\hline 7 & $\mathrm{a}$ & 5 & $\begin{array}{lllll} & c & a & d & e\end{array}$ \\
\hline 8 & $\mathrm{~b}$ & 5 & $\begin{array}{llll}\mathrm{b} & \mathrm{o} & \mathrm{p} & \mathrm{h}\end{array}$ \\
\hline 9 & $\mathrm{c}$ & 5 & $\begin{array}{lllll}a & e & b & c & d\end{array}$ \\
\hline 10 & $\mathrm{z}$ & 5 & $\begin{array}{lllll}q & v & y & n & z\end{array}$ \\
\hline 11 & $\mathrm{~s}$ & 5 & $\begin{array}{lllll} & \mathrm{s} & \mathrm{a} & \mathrm{b} & \mathrm{c}\end{array}$ \\
\hline 12 & $\mathrm{D}$ & 7 & $\begin{array}{lllllll}A & b & E & D & S & t & Z\end{array}$ \\
\hline 13 & $\mathrm{j}$ & 7 & $\begin{array}{lllllll}a & j & D & g & C & Z & S\end{array}$ \\
\hline 14 & $\mathrm{e}$ & 7 & $\begin{array}{llllllll}x & E & h & F & L & 1 & y\end{array}$ \\
\hline 15 & $\mathrm{H}$ & 7 & 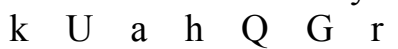 \\
\hline
\end{tabular}

Mastery Motivation (MM) Search Tasks

The Letter Search and Number Search tasks are primarily used to obtain measures of focused persistence on moderately challenging and challenging tasks (MM), but they also provide measures of competence on the tasks. As Table 4 shows, each child attempts one easy, two moderately difficult, and one hard level of each task, for up to two minutes each. Note that the figures 
and narratives presented here do not show all levels of each task. The easier levels of the letter search tasks have different rules and directions than the more difficult levels (6-8).

Table 4.

Levels of the Search Tasks Used at Different Ages

\begin{tabular}{lcccc}
\hline Age & Easy & $\begin{array}{c}\text { Moderately } \\
\text { challenging 1 }\end{array}$ & $\begin{array}{c}\text { Moderately } \\
\text { challenging 2 }\end{array}$ & Hard \\
\hline Less than 4 & 1 & 2 & 3 & 5 \\
$4-5$ & 1 & 3 & 4 & 6 \\
$5-6$ & 2 & 4 & 5 & 7 \\
$6-7$ & 3 & 5 & 6 & 8 \\
7 or more & 4 & 6 & 7 & 8 \\
\hline
\end{tabular}

Training. The screen shows a target object in the upper left. The middle of the screen displays a $2 \times 4$ matrix of 8 pictures, two each of identical pictures of four familiar objects: boat, house, banana, and car. Little Bear says:

Now we are going to play a different game. Over here is a boat (it flashes). Over here there are eight pictures (they flash). Touch all the pictures of the boat.

If children touch both of the boats, Little Bear says, "That's right." If children make a mistake, Little Bear corrects them, saying, "That is a , not a boat." This serves as the training for both search tasks. It occurs before the first search task, whether it is number search or letter search. If the child touches both boats and no other objects, level 1 of the number or letter search starts; if not, another example trial is given. For all other trials, the child is not told whether or not the response is correct.

Task 3 or 4. Number Search (Tasks 3 and 4 are counterbalanced). Little Bear says:

This is the Number Search game. In this game you will find the numbers. Over here, you see a number (number flashes) that is in a red box. The other numbers are in blue boxes. You will need to touch all of the blue numbers that are exactly the same as the red number. During these games we will not tell you if you have found them all.

Little Bear appears on the screen.

When you think you are done with this level and want to move on to the next, just click on me! I'll be right here!

Figure 2 and Table 5 show level 3 and all 8 levels of the number search task. 


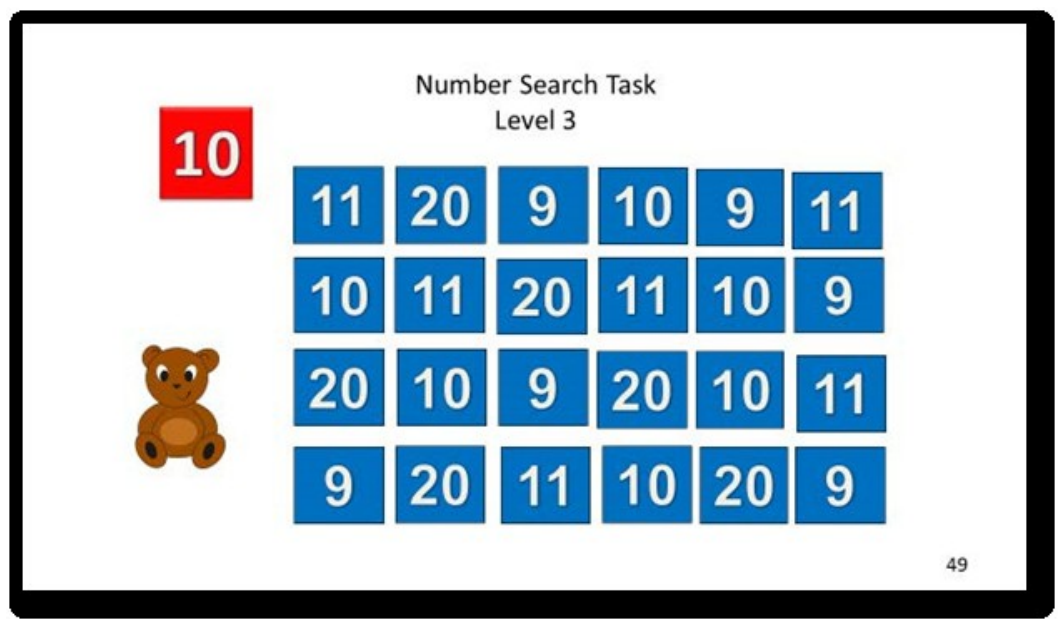

Figure 2. Level 3 of the number search task, a moderately challenging level for 4-year-olds.

Table 5.

Levels of the Number Search Task

\begin{tabular}{lccccc}
\hline Level & $\begin{array}{l}\text { N of target } \\
\text { Digits }\end{array}$ & $\begin{array}{c}\text { Numbers in } \\
\text { blue boxes }\end{array}$ & $\begin{array}{l}\text { Numbers in } \\
\text { order? }\end{array}$ & $\begin{array}{c}\text { N of matching } \\
\text { numbers }\end{array}$ & $\begin{array}{c}\text { Non-matching } \\
\text { numbers }\end{array}$ \\
\hline 1 & $1(2)$ & $8(4 * 2)$ & NA & 2 & 6 \\
2 & $1(3)$ & $12(4 * 3)$ & NA & 3 & 9 \\
3 & $2(10)$ & $24(6 * 4)$ & yes & 6 & 18 \\
4 & $2(25)$ & $30(6 * 5)$ & yes & 9 & 21 \\
5 & $3(746)$ & $30(6 * 5)$ & yes & 9 & 21 \\
6 & $3(109)$ & $30(6 * 5)$ & yes & 9 & 21 \\
7 & $4(6283)$ & $30(6 * 5)$ & yes & 9 & 21 \\
8 & $4(9639)$ & $30(6 * 5)$ & yes & 9 & \\
\hline
\end{tabular}

Figure 3 shows the easiest level of the letter search tasks, which is appropriate for children less than 5 years of age.

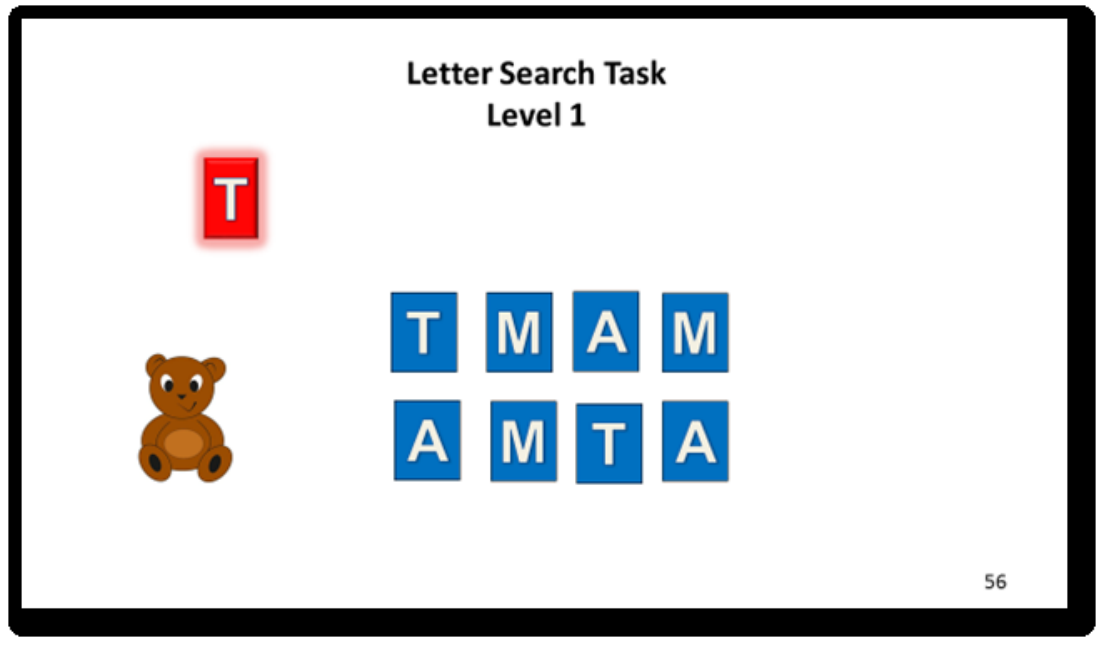

Figure 3. Level 1 of the letter search task, an easy task for 3 year-olds. 
Task 4 or 3. Letter Search Part 1 (Levels 1-5). Little Bear says,

Now we are going to play a game where you find letters. Over here, you will see a letter (letter flashes) that is in a red box. The other letters are in blue boxes. You will need to touch all of the blue letters that are the same as the red letter.

I'm still right here, so when you want to go to the next level, just touch me.

Then the tablet presents the easy level for that child's age group (see Table 4), followed by all moderate levels for that child's age group that are no higher than level 5 . It does not present levels 6-8 until additional training is provided for these highest levels, which have different rules. Figure 4 shows level 5 of the letter search tasks, which is moderately challenging for a 5-7 year old child.

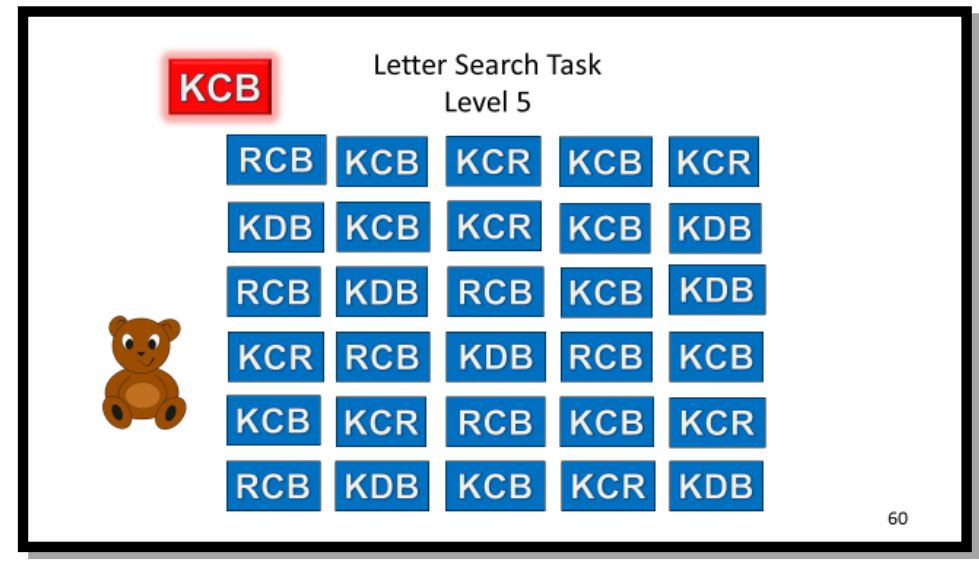

Figure 4. Level 5 of the letter search task, which is moderately challenging for 5-7 year-olds.

The five levels of Part 1 of the letter search task are described in Table 6.

Table 6.

Levels 1-5 of the Letter Search Task

\begin{tabular}{lccccc}
\hline Level & $\begin{array}{c}\text { N of target } \\
\text { letters }\end{array}$ & $\begin{array}{c}\text { Letters in blue } \\
\text { boxes }\end{array}$ & $\begin{array}{c}\text { Letters in or- } \\
\text { der? }\end{array}$ & $\begin{array}{c}\text { N of matching } \\
\text { letters }\end{array}$ & $\begin{array}{c}\text { Non-matching } \\
\text { letters }\end{array}$ \\
\hline 1 & $1(\mathrm{~T})$ & $8(4 * 2)$ & NA & 2 & 6 \\
2 & $1(\mathrm{~A})$ & $12(4 * 3)$ & NA & 3 & 9 \\
3 & $2(\mathrm{CO})$ & $24(6 * 4)$ & yes & 6 & 18 \\
4 & $2(\mathrm{GAM})$ & $30(6 * 5)$ & yes & 9 & 21 \\
5 & $3(\mathrm{KCB})$ & $30(6 * 5)$ & yes & 9 & 21 \\
\hline
\end{tabular}

The three levels of Part 2 of the letter search are described in Table 7. 
Table 7.

Levels 6-8 of the Letter Search Task

\begin{tabular}{llllll}
\hline Level & $\begin{array}{l}\text { N of target } \\
\text { letters }\end{array}$ & $\begin{array}{l}\text { Letters in blue } \\
\text { boxes }\end{array}$ & $\begin{array}{l}\text { Letters } \\
\text { in order? }\end{array}$ & $\begin{array}{l}\text { N of matching letters (matches } \\
\text { in parenthesis) }\end{array}$ & $\begin{array}{l}\text { Non-matching } \\
\text { letters }\end{array}$ \\
\hline 6 & $2(\mathrm{JK})$ & $30\left(6^{*} 5\right)$ & no & $4(\mathrm{JK}), 5(\mathrm{KJ})$ & 21 \\
7 & $2(\mathrm{VW})$ & $30\left(6^{*} 5\right)$ & no & $4(\mathrm{VW}), 5(\mathrm{WV})$ & 21 \\
8 & $3(\mathrm{JKG})$ & $30\left(6^{*} 5\right)$ & no & $3(\mathrm{JKG}), 3(\mathrm{KGJ}), 3(\mathrm{GJK})$ & 21 \\
\hline
\end{tabular}

Task 5: Letter Search Part 2 (Levels 6-8). Levels 6-8 require that the child find the same letters, regardless of the order in which they are pictured. Because the letters do not form words, the order is unimportant. (In contrast, because ordering numbers differently always changes the numerical value represented, there is no comparable task for number search.) After additional training (with pictures of flowers and boats) to teach children to ignore order in finding matches, these more difficult levels of the letter search are presented. See, for example, Figure 5. The child is given these instructions by Little Bear:

Now you get to play the new letter game, which has the same rule as the flower and boat game you just tried. In this game you will find several letters in a red box over here (box flashes). The other letters are in blue boxes. You will need to touch all of the groups of blue letters that are the same letters as the red letters. The blue letters can be in any order as long as they are the same as the red letters. Find JK and also KJ.

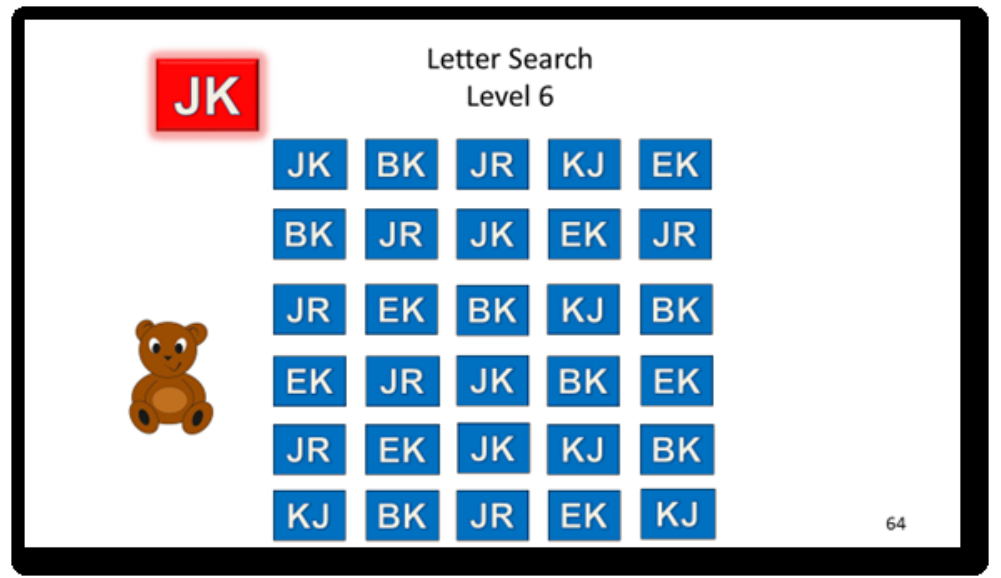

Figure 5. Level 6 of the letter search task: letters are found in either order. This is a hard task for 4-year-olds and moderately challenging task for 6 and 7-year-olds.

When the child finishes the last level of Session 1, Little Bear says, "It was good to play with you! Let's play again soon!" 


\section{Session Two of the Tasks}

\section{Executive Functions Tasks}

Each child receives one task that is typically easy at the child's age, one moderate task, and one hard task, as shown on Table 8.

Table 8. Task Levels Used at Different Ages for Both EF Tasks

\begin{tabular}{lccc}
\hline Age & Easy & Moderately challenging & Hard \\
\hline Less than 4 & 1 & 2 & 4 \\
$4-5$ & 1 & 3 & 5 \\
$5-6$ & 2 & 4 & 6 \\
$6-7$ & 3 & 5 & 7 \\
7 or more & 4 & 6 & 8 \\
\hline
\end{tabular}

Task 6 or 7. Picture Memory (Tasks 6 and 7 are counterbalanced). In this task the child sees a rectangular array of blank cards, which have pictures on the other side. When the child touches the blank card, the computer turns it over so that the picture is visible. Little Bear explains it as follows:

This is the picture memory game. In this game, you will find pictures that are the same. Touch a card to see what picture it is and then touch another card to try to find the same picture. For example, if you touch a card that is a fish, touch another card to see if it is the other fish. If the other card is also a fish you have found what you are looking for. If you find a picture that isn't the same, then keep playing.

If children do not find the match, they are expected to keep trying by touching one card at a time until they find the match. For levels 1-5, when the child touches a matching card, both cards disappear, but when a non-matching card is touched, it flips back (see Figure 6). However, in the more difficult levels 6-8, all cards flip back over and remain in the same place on the screen after they are touched.

"Let's start. Find all the cards that are the same as each other." 


\section{Picture Memory \\ Level 1}
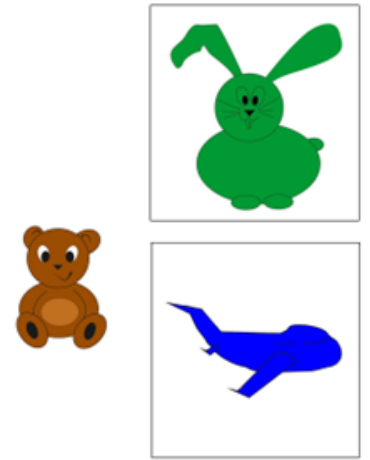
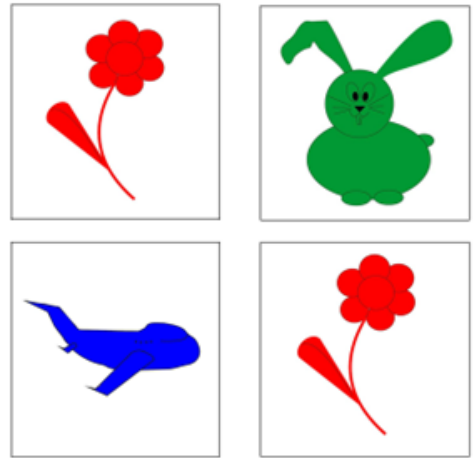

Figure 6. Level 1 of picture memory task, an easy level for 3 and 4-year-olds. Note the children will not see any of the pictures on the screen until they touch one at-a-time.

Children aged 5 years and older receive at least one task from levels 6-8. The tablet gives them instructions about the "new," harder game where the cards don't disappear when they are matched (see Figure 7).

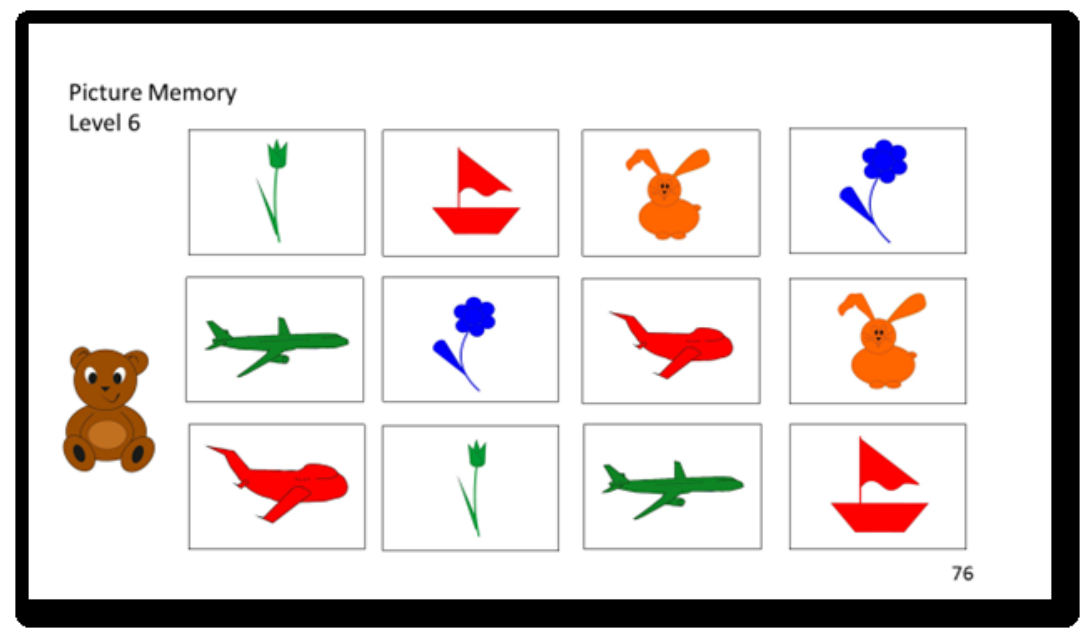

Figure 7. Level 6 for the picture memory task, with somewhat fewer pictures than level 4 and 5 but where the cards do not disappear when matched. This task is considered hard for 5-year-olds and moderately challenging for 7-year-olds.

Table 9 shows all eight levels of the Picture Memory task, including: (a) the number of pairs of pictures, (b) the total number of pictures in the array, and (c) whether both cards disappear when they are matched or the cards turn back over when matched rather than disappearing. 
Table 9.

Levels of the Picture Memory Task

\begin{tabular}{cccc}
\hline Level & N of pairs & N on screen & Matched cards disappear \\
\hline 1 & 3 & 6 & yes \\
2 & 4 & 8 & yes \\
3 & 6 & 12 & yes \\
4 & 8 & 16 & yes \\
5 & 12 & 24 & yes \\
6 & 6 & 12 & no \\
7 & 8 & 16 & no \\
8 & 12 & 24 & no \\
\hline
\end{tabular}

Task 7 or 6. Size-Shape-Color Game. Figure 8 shows the general layout on the screen for the Size-Shape-Color tasks. The red sailboat on the bottom of the screen is the one that changes for each trial, and which the child can drag into one or the other of two baskets depending on the sorting dimension specified (the game being played). Instructions vary with the specific task.

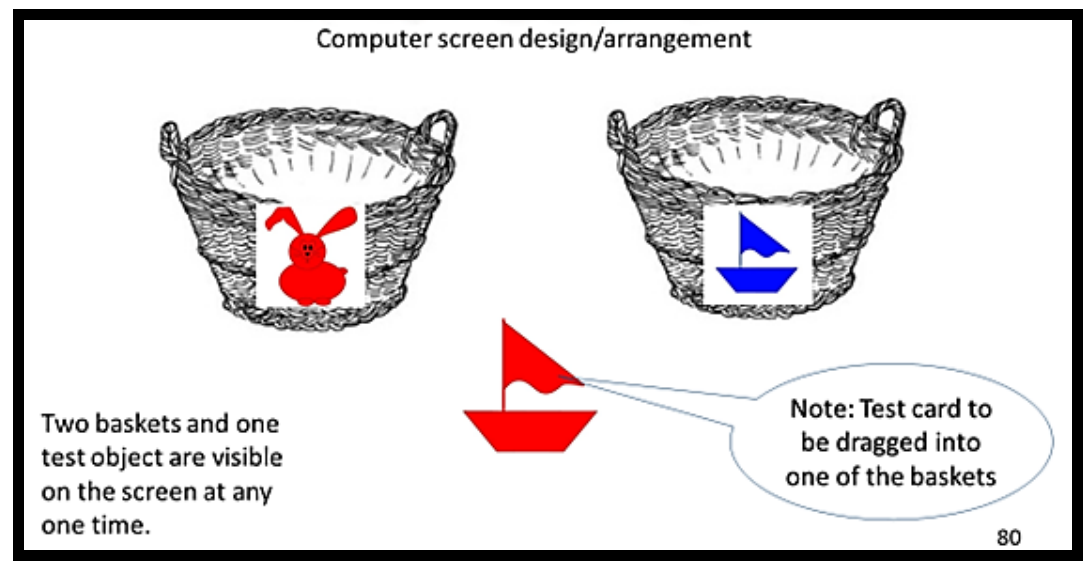

Figure 8 . The general design of the screen for the dimensional change card sort tasks. For levels $1-6$, there are two baskets and one test object or card on the screen at any one time.

Sometimes, children "play the shape game", in which the child drags the test card into the basket with the same shape, ignoring color. For example, blue rabbits go in the basket with the red rabbit on it, and red boats go in the basket with the blue boat on it, even though the colors don't match. In the "color game," red boats go in the basket with the red bunny, and blue bunnies go in the basket with blue boat. In the "size game," all of the big objects go in the basket with the big picture on it and all the little objects go in the basket with the little picture on it. Importantly, the cards that are sorted never exactly match the pictures on the baskets. Children are told wheth- 
er the sorting is correct on training trials but not on the test trials. After the training, Little Bear starts the actual task by saying,

We're going to play a game with colors and shapes. You will sort 'pictures' into two baskets. During each game, we will tell you the rule you will use to sort pictures.

Level 1: Pre-Switch

Now we are going to play the color game. In the color game, you put all of the red ones in this basket (it flashes) and all of the blue ones in this basket (it flashes). Each time you see a new card, put it in the red basket if it is red and the blue basket if it is blue.

\section{Level 1: Post Switch}

Now we are going to play the shape game. Put the flower cards in the flower basket and the airplane in the airplanes basket.

Level 7 Pre Switch (7a): Size sorting is demonstrated but the child is not told to sort by size

Levels $7 \mathrm{a}$ and $\mathrm{b}$ are the hard card sort tasks for 6-year-olds (see Figure 9).

Now you are going need to figure out what game we are playing by how I sort the cards. First watch me to find out what game we are playing. See this one goes in this basket."

The computer puts the large orange bunny in the basket with the large orange boat.

This is the same card, so I need to see if there is another basket that it goes in.

There it is! It goes in this one.

The computer puts the large orange bunny in the basket with the two large green bunnies.

"This one goes in this basket AND this one." The small green boat goes in the basket with the small green bunny and also in the basket with the two small boats. So the computer has demonstrated size sorting again.

Now you do it. Make sure that you put all of the same card in ALL of the baskets it belongs in. If it belongs in more than one basket, don't put it in the same basket twice, put it in the other correct one. 


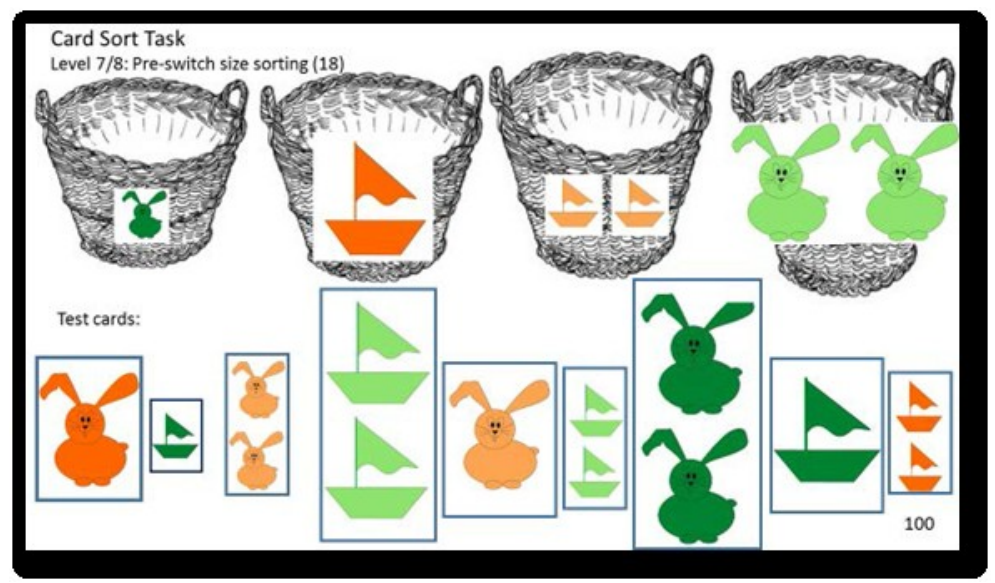

Figure 9. Levels $7 \mathrm{a}$ and $8 \mathrm{a}$ of the card sort task. Size sorting is demonstrated but the computer does not give verbal instructions to the child on how to sort. Level $7 \mathrm{a}$ and $\mathrm{b}$ are intended to be difficult for 6-year-olds.

Level 7b Post Switch: Color sorting is demonstrated but the child is not told to sort by color

The same four baskets and nine test cards are used for $7 \mathrm{~b}$ Post switch color sorting.

"OK, now we're playing a different game. Watch how I sort it this time. Now you do it."

Level $8 \mathrm{a}$ and $\mathrm{b}$ are the hard card sort tasks for children aged 7 or older. See Table 10 for more information.

Level 8b Post Switch (see Figure 10):

“OK, now we're playing a different game, watch how I sort it again. Now you do it.

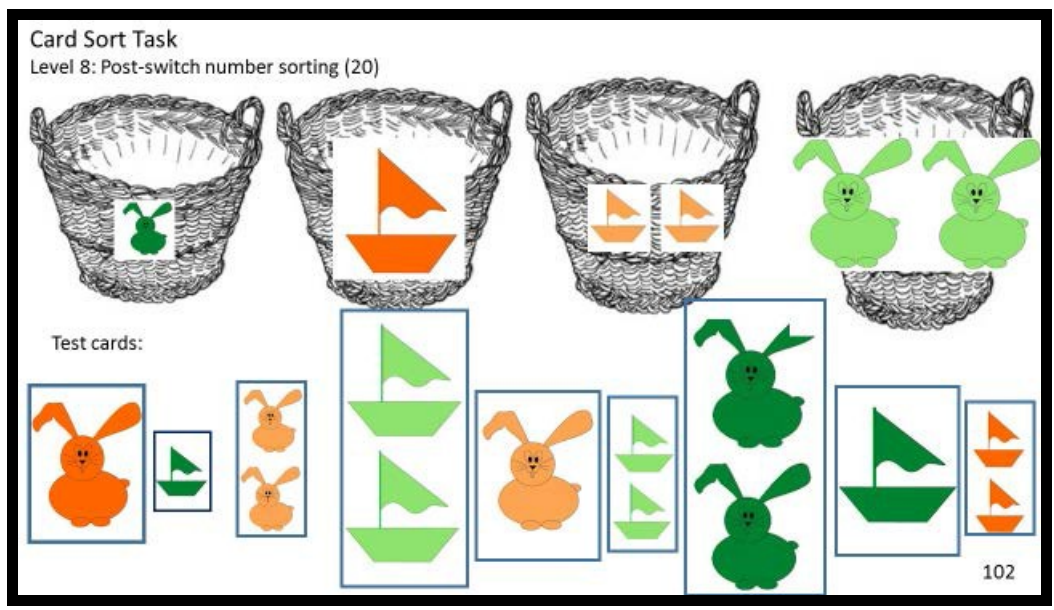

Figure 10. Level 8b: Number sorting is demonstrated but the child is not told to sort by number 
Table 10.

\begin{tabular}{|c|c|c|c|c|c|c|c|}
\hline Level & $\begin{array}{c}\mathrm{N} \text { of } \\
\text { baskets }\end{array}$ & $\begin{array}{l}\mathrm{N} \text { of } \\
\text { cards }\end{array}$ & Pictures sorted & $\begin{array}{l}\text { Pictures on } \\
\text { baskets }\end{array}$ & $\begin{array}{l}\text { Pre-switch } \\
\text { dimension }\end{array}$ & $\begin{array}{c}\text { Post-Switch } \\
\text { dimension }\end{array}$ & $\begin{array}{l}\text { 2nd post-switch } \\
\text { dimension }\end{array}$ \\
\hline 1 & 2 & 6 & $\begin{array}{l}\text { Red airplane } \\
\text { Blue flower }\end{array}$ & $\begin{array}{l}\text { Red flower; } \\
\text { Blue airplane; }\end{array}$ & Color & Shape & NA \\
\hline 5 & 2 & 9 & $\begin{array}{l}\text { Orange big bun- } \\
\text { ny } \\
\text { Green little boat } \\
\text { Orange little } \\
\text { bunny } \\
\text { Green big boat }\end{array}$ & $\begin{array}{c}\text { Green little } \\
\text { bunny; } \\
\text { Orange big } \\
\text { boat }\end{array}$ & Size & Opposite size & $\begin{array}{l}\text { Mixed, with } 6 \\
\text { opposite } \\
\text { size and } 3 \text { size }\end{array}$ \\
\hline 8 & 4 & 9 & $\begin{array}{c}\text { Orange big bun- } \\
\text { ny } \\
\text { Dark green little } \\
\text { boat } \\
\text { Light orange } \\
\text { little bunnies } \\
\text { Light green big } \\
\text { boats } \\
\text { Light orange big } \\
\text { bunny } \\
\text { Light green little } \\
\text { boats } \\
\text { Dark green big } \\
\text { bunnies } \\
\text { Dark green big } \\
\text { boat } \\
\text { Orange little } \\
\text { boats }\end{array}$ & $\begin{array}{l}1 \text { Little dark } \\
\text { green } \\
\text { bunny } \\
1 \text { Big dark } \\
\text { orange } \\
\text { boat } \\
2 \text { Little light } \\
\text { orange } \\
\text { boats } \\
2 \text { Big light } \\
\text { green } \\
\text { bunnies }\end{array}$ & 8a Size & 8b Number & \\
\hline
\end{tabular}

When the child finishes the last executive functions task, Little Bear says "goodbye".

\section{Conclusions and implications}

Our current pilot work with over 250 Hungarian children supports the reliability and validity of our internet-based version (see Józsa et al., 2017); we are now piloting the android version with U.S. and Hungarian children. Eventually, we hope to make the assessment available to school systems, so that they can use it to assess school readiness and school success. We also plan to make it available to researchers interested in $\mathrm{MM}, \mathrm{EF}$, and school readiness. We plan to use Item Response Theory and parent, teacher, and observer report methods to assess difficulty level, reliability, and validity across the full range of abilities and motivation levels that are ob- 
servable from age 3 to age 8 . We believe that the tasks will be most useful in schools as one part of a larger assessment of school readiness using additional measures such as DIFER. The data collected by the app will provide individualized information, enabling the development of individualized intervention/remediation plans. Future data collection will enable standardization of the assessment, based on a larger, more diverse set of participants from Hungary, the US, and other countries and languages.

There is a strong need for well-designed, reliable and valid tests of approaches to learning, especially MM and EF, for children in preschool and the early school grades. Currently, there are many tests of IQ and basic achievement skills, and there are questionnaire assessments of concepts such as intrinsic motivation, mastery motivation, and executive functions. However, to our knowledge there are no standardized behavioral tests including both children's mastery motivation and executive functions, and no computer tablet app assessments of these skills. Thus, such a test will fill a void in a very large Hungarian, US, and international market. The android app will enable children to do the tasks even when internet access is inconsistent or unavailable. Because the computer tablet essentially administers the tasks and collects the data needed for the analyses, data collection will not require much teacher time or training. Therefore, we believe that, using our new android app, we will soon have sufficient data to demonstrate feasibility, reliability, and validity of these computer tablet-based tasks. After this pilot data collection is completed, we also plan to create an iOS app. A longer-term plan is to create tablet-based individualized interventions based on the assessment.

High quality early childhood education has an extraordinarily high return on investment, given its association with improved school performance and with decreases in later school dropout, delinquent and other risky behaviors (e.g., Akers et al., 2015; Rathbun \& Zhang, 2016). In Hungary, in the US, and, indeed, throughout Europe and Asia, early childhood education and school readiness set the stage for all future education, and the importance of individualized assessments of school readiness and individualized curriculum to remediate any deficiencies are increasingly acknowledged. Our tablet-based assessment thus will fill an important need, enabling schools to assess each individual child's level of development on each task, and to develop 
high quality, individualized remediation and enrichment efforts to improve the performance of our next generation of learners.

\section{Acknowledgements}

The research was supported by the Hungarian National Research, Development and Innovation Office, NKFI K124839 and Colorado State University Ventures Grant. Krisztián Józsa also was supported by the János Bolyai Research Scholarship of the Hungarian Academy of Sciences. The authors thank Amanda Dillard, Gabriella Józsa, and Noémi Kis for their assistance.

\section{References}

Akers, L., Del Grosso, P., Atkins-Burnett, S., Monahan, S., Boller, K., Carta, J., \& Wasik, B. A. (2015). Tailored teaching: The need for stronger evidence about early childhood teachers' use of ongoing assessment to individualize instruction. Research Brief OPRE Report \#2015-59. Washington, DC: Mathematica Policy Research.

Barrett, K. C., \& Morgan, G. A. (1995). Continuities and discontinuities in mastery motivation in infancy and toddlerhood: A conceptualization and review. In R. H. MacTurk \& G. A. Morgan (Eds.), Mastery motivation: Origins, conceptualizations, and applications (pp. 67-93). Norwood, NJ: Ablex.

Barrett, K. C., Józsa, K., \& Morgan, G. A. (2017). New computer-based mastery motivation and executive function tasks for school readiness and school success in 3 to 8 year-old children. Hungarian Educational Research Journal, 7(2), 89-108. doi:10.14413/h34j.2017.02.06

Berhenke, A., Miller, A. L, Brown E., Seifer, R., \& Dickstein, S. (2011). Observed emotional and behavioral indicators of motivation predict school readiness in Head Start graduates. Early Childhood Research Quarterly, 26, 430-441.

Bierman, K. L., \& Torres, M. (2016). Promoting the development of executive functions through early education and prevention programs. In J. A. Griffin, P. McCardle, \& L.S. Freund (Eds.). Executive Function in Preschool-Age Children: Integrating Measurement, Neuro- 
development, and Translational Research (pp. 299-326). Washington, DC: American Psychological Association.

Blair, C., \& Razza, R. P. (2007). Relating effortful control, executive function, and false belief understanding to emerging math and literacy ability in kindergarten. Child Development, 78, 647-663. doi:10.111/j.1467-8624.2007.01019.x

Blair, C., \& Raver, C. C. (2015). School Readiness and self-regulation: A developmental psychobiological approach. Annual Review of Psychology, 66, 711-731.

Bryck, R. L., \& Fisher, P. A. (2012). Training the brain: Practical applications of neural plasticity from the intersection of cognitive neuroscience, developmental psychology, and prevention science. American Psychologist, 67, 87-100. doi:10.1037/a0024657

Busch-Rossnagel, N. A., \& Morgan, G. A. (2013). Introduction to section three: Overview and analysis. In K. C. Barrett, N. A. Fox, G. A. Morgan, D. J. Fidler, \& L. A. Daunhauer (Eds.), Handbook on self-regulatory processes in development: New directions and international perspectives (pp. 247-264). New York, NY: Psychology Press.

Csapó, B., Molnár, Gy., \& Nagy, J. (2014). Computer-based assessment of school readiness and early reasoning. Journal of Educational Psychology, 106(2), 639- 650.

Cuskelly, M., Gilmore, L., \& Carroll, A. (2013). Self-regulation and mastery motivation in individuals with developmental disabilities: Barriers, supports and strategies. In K. C. Barrett, N. A. Fox, G. A. Morgan, D. J. Fidler, \& L. A. Daunhauer (Eds.), Handbook on selfregulatory processes in development: New directions and international perspectives (pp. 381-402). New York, NY: Psychology Press.

Diamond, A., \& Lee, K. (2011). Interventions shown to aid executive function development in children 4 to 12 years old. Science, 333, 959-964.

Diamond, A. (2013). Executive function. Annual Review of Psychology, 64, 135-168.

Diamond, A. (2016). Why improving and assessing executive functions early in life is critical. In J. A. Griffin, P. McCardle, \& L. S. Freund (Eds.), Executive Function in Preschool-Age Children: Integrating Measurement, Neurodevelopment, and Translational Research (pp. 11-43). Washington, DC: American Psychological Association. doi:10.1037/4797-002

Greenberg, M. T., \& Harris, A. R. (2012). Nurturing mindfulness in children and youth: Current state of research. Child Development Perspectives, 6, 161-166. 
Guernsey, L., Bornfreund, L., McCann, C., \& Williams, C. (2014). Subprime learning: Early education in America since the Great Recession. New Americal Education Policy Program, 1-25.

Hashmi, S. I., Seok, C. B., \& Halik, M. H. (2017). Enhancing persistence on mastery tasks among young preschool children by implementing the "I Can" mastery motivation classroom program. Hungarian Educational Research Journal, 7(2), 129-143.

Hauser-Cram, P., Warfield, M. E., Shonkoff, J. P., \& Krauss, M. W. (2001). Children with disabilities: A longitudinal study of child development and parent well-being. Monographs of Society for Research in Child Development, 66, Serial No. 266.

Hyson, M. (2008). Enthusiastic and engaged learners: Approaches to learning in the early childhood classroom. New York: Teachers College Press.

Józsa, K. (2001, August). The relationship between mastery motivation and basic cognitive skills at age 4-12. Paper presented at the $9^{\text {th }}$ European Conference for Research on Learning and Instruction, Fribourg, 94.

Józsa, K. (2003). The development of mastery motivation and its relationship to basic cognitive skills in children 4 to 16. PhD dissertation. Szeged, Hungary: University of Szeged.

Józsa, K. (2007). Az elsajátítási motivació [Mastery motivation]. Budapest, Hungary: Müszaki Kiadó. (in Hungarian)

Józsa, K. (2014a). Developing new scales for assessing English and German language mastery motivation. In J. Horvath \& P. Medgyes (Eds.), Studies in honour of Marianne Nikolov (pp. 37-50). Pécs: Lingua Franca Csoport.

Józsa, K. (2014b). Improving pre-mathematics skills from age 4 to 8. Szeged: Mozaik Kiadó. (in Hungarian)

Józsa, K. (2016). Challenges and possibilities in preschool improvement programs. Iskolakultúra, 26(4), 59-74. (in Hungarian)

Józsa K., \& Barrett, K. C. (2016). Predicting School Related Skills and Early School Achievement in Hungarian School-age Children from Mastery Motivation, IQ, and Parental Education: A Longitudinal Study. Submitted.

Józsa K., \& Barrett, K. C. (submitted). Affective and Social Mastery Motivation in Preschool as Predictors of Early School Success: A Longitudinal Study. 
Józsa, K., Barrett, K. C., Józsa, G., Kis, N., \& Morgan, G. A. (2017). Development and initial evaluation of an individualized moderately challenging computer-tablet mastery motivation measure for 3-8 year-olds. Hungarian Educational Research Journal, 7(2), 109-128. doi:10.14413/herj.2017.02.07

Józsa, K., Barrett, K. C., \& Morgan, G. A. (2016, July). New Computer based Assessment of Mastery Motivation for Young Children. 24th Biennial Meeting of the International Society for the Study of Behavioural Development, ISSBD, July 10-14, 2016 Vilnius, Lithuania.

Józsa, K., \& Molnár, É. D. (2013). The relationship between mastery motivation, self-regulated learning and school success: A Hungarian and wider European perspective. In K. C. Barrett, N. A. Fox, G. A. Morgan, D. J. Fidler, \& L. A. Daunhauer (Eds.), Handbook of self-regulatory processes in development: New directions and international perspectives (pp. 265-304.) New York, NY: Psychology Press.

Józsa, K., \& Morgan, G. A. (2014). Developmental changes in cognitive persistence and academic achievement between grade 4 and grade 8. European Journal of Psychology of Education, 29(3), 521-535.

Józsa, K., Wang, J., Barrett, K. C., \& Morgan, G. A. (2014). Age and cultural differences in selfperceptions of mastery motivation and competence in American, Chinese, and Hungarian school-age children. Child Development Research, 2014, Article ID 803061.

Kagan, S. L., Moore, E., \& Bradekamp, S. (Eds.), (1995). Reconsidering children's early learning and development: Toward common views and vocabulary. Report of the National Education Goals Panel, Goal 1 Technical Planning Group, pg. 28. No. ED 391576. Washington, DC: U.S. Government Printing Office.

Martin, A., Razza, R.A., \& Brooks-Gunn, J. (2015). The Maternal Description of Child (MDoC): A new audiotaped measure of maternal affect. Infant and Child Development, 24, 228239.

McClelland, M. M., Cameron, C. E., Connor, C. M., Farris, C. L., Jewkes, A. M., \& Morrison, F. J. (2007). Links between behavioral regulation and preschoolers' literacy, vocabulary, and math skills. Developmental Psychology, 43(4), 947-959.

McDermott, P. A., Fantuzzo, J. W., Warley, H. P., Waterman, C., Angelo, L. E., Gadsden, V. L., \& Sekino, Y. (2011). Multidimentionality of teachers' graded responses for preschoolers' 
stylistic learning behavior: The Learning-to-Learn Scales. Educational and Psychological Measurement, 71, 148-169.doi:10.1177/0013164410387351

McDermott, P. A., Rikoon, S. H., Waterman, C., \& Fantuzzo, J. W. (2012). The Preschool Learning Behaviors Scale: Dimensionality and external validity in Head Start. School Psychology Review, 41, 66-81.

McWayne, C. M., Cheung, K., Wright, L. G., \& Hahs-Vaughn, D. L. (2012). Patterns of school readiness among head start children: Meaningful within-group variability during the transition to kindergarten. Journal of Educational Psychology, 104(3), 862-878. doi:10.1037/a0028884

Morgan, G. A., Busch-Rossnagel, N. A., Maslin-Cole, C. A., \& Harmon, R. J. (1992). Individualized assessment of mastery motivation: manual for 15 to 36 month old children. Colorado State University, Fort Collins. Retrieve from https://sites.google.com/a/rams.colostate.edu/georgemorgan/mastery-motivation

Morgan, G. A., Harmon, R. J., \& Maslin-Cole, C. A. (1990). Mastery motivation: Definition and measurement. Early Education and Development, 1, 318-339.

Morgan, G. A., Wang, J., Liao, H-F., \& Xu, Q. (2013). Using the Dimensions of Mastery Questionnaire (DMQ) to assess mastery motivation of English and Chinese speaking children: Psychometrics and implications for self-regulation. In K. C. Barrett, N. A. Fox, G. A. Morgan, D. J. Fidler, \& L. A. Daunhauer (Eds.), Handbook on self-regulatory processes in development: New directions and international perspectives (pp. 305-335). New York, NY: Psychology Press.

Müller, U., \& Kerns K. (2015). The development of executive function. In Lerner, R. M. (Ed.), Handbook of Child Psychology and Developmental Science (pp. 571-623). New York: John Wiley \& Sons.

Nagy, J., Józsa, K., Vidákovich, T., \& Fazekasé Fenyvesi, M. (2004b). Az elemi alapképességek fejlödése 4-8 éves életkorban. Az eredményes iskolakezdés hét kritikus alapkészségének országos helyzetképe és a pedagógiai tanulságok [The development of elementary skills between the ages of 4 and 8 . A national overview of the seven basic skills needed for academic success and their pedagogic consequences]. Szeged, Hungary: Mozaik Kiadó. (in Hungarian) 
Nagy, J., Józsa, K., Vidákovich, T., \& Fazekasné Fenyvesi, M. (2004a). DIFER Programcsomag: Diagnosztikus fejlődésvizsgáló és kritériumorientált fejlesztö rendszer 4-8 évesek számára. [DIFER: A diagnostic system of assessment and criterion-referenced development between the ages of 4-8.] Szeged: Mozaik Kiadó. (in Hungarian)

Peterson, E., \& Welsh, M. C. (2014). The development of hot and cool executive functions in childhood and adolescence: Are we getting warmer? In S. Goldstein, \& J. A. Naglieri (Eds.), Handbook of Executive Functioning (pp. 45- 65). London: Springer.

Ratelle, C.F., Guay, F., Larose, S., \& Senécal, C. (2004). Family correlates of trajectories of academic motivation during a school transition: A semiparametric group-based approach. Journal of Educational Psychology, 96, 743- 754.

Rathbun, A., \& Zhang, A. (2016) Primary early care and education arrangements and achievement at kindergarten entry. (NCES 2016-070). National Center for Education Statistics, U.S. Department of Education. Washington, DC.

Sakiz, G. (2017). Perceived teacher affective support in relation to emotional and motivational variables in elementary school science classrooms in Turkey, Research in Science \& Technological Education, 35, 108- 129, doi:10.1080/02635143.2017.1278683

Sasser, T. R., Bierman, K. L., \& Heinrichs, B. (2015). Executive functioning and school adjustment: The mediational role of pre-kindergarten learning-related behaviors. Early Childhood Research Quarterly, 30, 70- 79. doi:10.1016/j.ecresq.2014.09.001

Schiefele, U., \& Schaffner, E. (2015). Teacher interests, mastery goals, and self-efficacy as predictors of instructional practices and student motivation. Contemporary Educational Psychology, 42, 159- 171. doi:10.1016/j.cedpsych.2015.06.005

Shonkoff, J. P., \& Phillips, D. (2000). Setting the stage: Introduction. In J. P. Shonkoff \& D. Phillips (Eds.), From neurons to neighborhoods: The science of early childhood development (pp. 19-38). Washington, DC: National Academies Press.

Vansettenkiste, M., Simons, J., Lens, W., Sheldon, K. M., \& Deci, E. L. (2004). Motivating learning, performance, and persistence: The synergistic role of intrinsic goals and autonomy- support. Journal of Personality and Social Psychology, 87, 246-260.

Wang, J., \& Barrett, K. C. (2013). Mastery motivation and self-regulation during early childhood. In K. C. Barrett, N. A. Fox, G. A. Morgan, D. J. Fidler, \& L. A. Daunhauer (Eds.), 
Handbook on self-regulatory processes in development: New directions and international perspectives (pp. 337-380). New York, NY: Psychology Press.

Wang, P. J., Morgan, G. A., Hwang, A. W., \& Liao, H. F. (2013). Individualized behavioral assessments and maternal ratings of mastery motivation in mental age-matched toddlers with and without motor delay. Physical Therapy, 93(1), 79-87.

Wang, P. J., Morgan, G. A., Liao, H-F. Chen, L-C., Hwang, A-W., \& Lu, L. (2016). Convergent Validity and Reliability of Revised Individualized Structured Mastery Tasks (ISMT-R) In Children with Developmental Delay. International Society on Early Intervention (ISEI) Conference, June 8-10, 2016 Stockholm, Sweden.

Willoughby, M.T., Blair, C.B., Wirth, R.J., Greenberg, M., \& the Family Life Project Investigators (2012). The measurement of executive function at age 5: Psychometric properties and relationship to academic achievement. Psychological Assessment, 24(1), $226-239$.

Yarrow, L. J., Klein, R.P., Lomanaco, S., \& Morgan, G.A. (1975). Cognitive and motivational development in early childhood. In B. Z. Friedlander, G. M. Sterritt, \& G. E. Kirk (Eds.), Exceptional infant, assessment and intervention (pp. 491-502). New York: Bruner/Mazel.

Zelazo, P. D. (2006). The Dimensional Change Card Sort (DCCS): A method of assessing executive function in children. Nature Protocols, 1, 297-301.

Zelazo, P. D., \& Müller, U. (2002). Executive function in typical and atypical development. In U. Goswami (Ed.), Blackwell handbook of childhood cognitive development (pp. 445-469). Oxford: Blackwell.

Zelazo, P. D., \& Müller, U. (2010). Executive function in typical and atypical children. In U. Goswami (Ed.), The Blackwell-Wiley handbook of childhood cognitive development (2nd rev. ed., pp. 574-603). Oxford, England: Blackwell.

Zelazo, P. D., Blair, C. B., \& Willoughby, M. T. (2016). Executive function: Implications for education (NCER 2017-2000). Washington, DC: National Center for Education Research, Institute of Education Sciences, U.S. Department of Education. 